\title{
BERAT POTONG, BERAT KARKAS DAN PERSENTASE KARKAS TERNAK SAPI POTONG LOKAL YANG DIPOTONG DI RUMAH POTONG HEWAN MANADO
}

\author{
Fernando Andris Marino, A. Lomboan*, E. Pudjihastuti, E.H.B. Sondakh \\ Fakultas Peternakan, Universitas Sam Ratulangi Manado, 95115
}

\begin{abstract}
ABSTRAK
Penelitian ini bertujuan untuk mengetahui berat potong, berat karkas dan persentase karkas ternak sapi potong lokal Sulawesi Utara yang dipotong di RPH Manado. Materi yang digunakan dalam penelitian ini adalah 40 ekor ternak sapi potong lokal Sulawesi Utara yang ada di RPH, Manado. Peralatan yang digunakan dalam penelitian ini ialah meteran dan timbangan gantung. Penelitian ini menggunakan metode observasi, wawancara langsung serta pengukuran yang dilakukan secara acak dan penimbangan untuk mengetahui berat potong, berat karkas dan persentase karkas. Hasil penelitian menunjukan bahwa nilai rataan berat potong $271,475 \mathrm{~kg} \pm 34,129$, berat karkas 136,025 $\mathrm{kg} \pm 16,477$ dan persentase karkas 50,168 \% \pm 1,694. Berdasarkan hasil penelitian disimpukan bahwa ternak sapi potong lokal yang di potong di RPH Manado masih tergolong rendah dilihat dari aspek berat potong dan berat karkas.
\end{abstract}

Kata kunci : Sapi Potong, Berat, RPH

\section{ABSTRACT}

SLAUGHTER

WEIGHT

CARCASS WEIGHT AND THE PERCENTAGE OF CARCASSES OF NORTH SULAWESI LOCAL BEEF CATTLE CUT IN SLAUGHTER. The study aims to determine the slaughter weight, carcass weight and the percentage

Korespondensi (correspondingauthor)

Email : agustinuslomboan@yahoo.co.id of carcasses of North Sulawesi local beef cattle cut in RPH Manado. The material used in this study were 40 local North Sulawesi beef cattle in RPH, Manado. The equipment used in this study is the meter and the hanging scales. This study uses the method of observation, direct interviews and measurements carried out randomly and weighing to determine the cut weight, carcass weight and carcass percentage. The results showed that the average value of $271,475 \mathrm{~kg} \pm 34,129 \mathrm{~kg}$ weight, carcass weight $136,025 \mathrm{~kg} \pm 16,477$ and the percentage of North Sulawesi local beef cattle carcass $50,168 \% \pm 1,694$. Based on the results of the study it was concluded that the cattle of North Sulawesi local beef cattle slaughtered in RPH Manado still relatively low in term of average weight of slaughter and carcass weight.

Keywords: Beef Cattle, Weight, Slaughterhouse

\section{PENDAHULUAN}

Meningkatnya jumlah penduduk, pertumbuhan ekonomi dan adanya perubahan pola konsumsi serta selera masyarakat telah menyebabkan konsumsi daging sapi secara nasional cenderung meningkat (Firdausi et al., 2012). Sulawesi Utara memiliki potensi yang besar untuk pengembangan usaha ternak sapi karena didukung oleh sumber daya alam (lahan, 
pakan), sumber daya manusia, serta peluang pasar yang memadai.

Salah satu ternak potong yang berpotensi untuk dioptimalkan pengembangannya adalah sapi peranakan ongole (PO) karena cocok dikembangkan di daerah tropis, mampu merespon dengan baik pada pemberian pakan berkualitas untuk menghasilkan karkas yang baik (Ngadiyono et al., 2008).

Rumah Potong Hewan (RPH) menurut Surat Keputusan Menteri Pertanian No. 555/ Kpts/ TN. 240/ 1986 adalah bangunan atau komplek bangunan dengan desain tertentu yang digunakan sebagai tempat memotong hewan selain unggas bagi konsumsi masyarakat. Indikator produksi daging dari seekor ternak pedaging bisa diukur dari berat dan persentase karkas yang dihasilkan sebab pada karkas terkandung otot yang selanjutnya akan terkonversi menjadi daging.

Sebagai hasil utama dari sapi pedaging khususnya sapi potong lokal Sulawesi Utara, maka data produksi karkas sangat diperlukan dan bermanfaat untuk merencanakan upaya pemenuhan permintaan daging dan pengembangan peternakan sapi dimasa yang akan datang.

Berdasarkan uraian diatas, maka telah dilakukan penelitian yang bertujan untuk mengetahui berat potong, berat karkas dan persentase karkas pada ternak sapi potong lokal Sulawesi Utara di RPH Manado.

\section{MATERI DAN METODE PENELITIAN}

Materi yang digunakan dalam penelitian ini adalah 40 ekor ternak sapi potong lokal Sulawesi Utara yang ada di RPH, Manado. Peralatan yang digunakan dalam penelitian ini ialah meteran dan timbangan gantung.

Penelitian ini menggunakan metode observasi, wawancara langsung serta pengukuran yang dilakukan secara acak dan penimbangan untuk mengetahui berat potong, berat karkas dan persentase karkas pada ternak sapi potong lokal Sulawesi Utara di RPH, Manado.

Data yang diambil dalam penelitian ini adalah berat potong, berat karkas, dan persentase karkas.

\section{Berat Potong}

Berat potong ternak diperoleh dengan cara mengukur lingkar dada dan panjang badan sapi menggunakan meteran dan kemudian data yang didapatkan dihitung menggunakan rumus Lambourne (Malewa, 2009).

$$
\text { Berat Potong }(\mathrm{kg})=\frac{\mathrm{LD}(\mathrm{cm})^{2}+\mathrm{PB}(\mathrm{cm})^{2}}{10840}
$$

\section{Berat Karkas}

Berat karkas dapat diperoleh dengan cara menimbang menggunakan timbangan 
gantung seluruh daging dan tulang setelah dikurangi darah, kepala, kulit, organ dalam dan keempat kaki.

\section{Persentase Karkas}

Persentase karkas diperoleh dengan membandingkan berat karkas dengan berat potong kemudian dikalikan 100\%. Data dianalisa secara deskriptif dengan menghitung berat potong, berat karkas, dan persentase karkas ternak sapi potong lokal Sulawesi Utara di Rumah Potong Hewan Manado.

\section{HASIL DAN PEMBAHASAN}

\section{Berat Potong}

Berdasarkan data penelitian pada Tabel 1 terlihat bahwa nilai rataan berat potong ternak sapi potong lokal Sulawesi Utara adalah 271,475 kg/ekor dengan kisaran 209 kg - 317 kg/ekor. Hasil penelitian yang diperoleh ini masih lebih kecil dibandingkan dengan hasil penelitan dari Yosita et al. (2012), yang memperoleh rataan berat potong $343,40 \mathrm{~kg}$. Hal yang sama juga diperoleh dari beberapa hasil penelitian lainnya, seperti dalam Carvalho et al. (2010) yang memperoleh berat potong sebesar 395,76 kg. Begitu pula dengan hasil yang diperoleh oleh Hafid et al. (2013) yang memperoleh rataan berat potong 448,36 kg. Rendahnya berat potong sapi pada hasil penelitian di RPH Manado, diduga disebabkan oleh faktor-faktor antara lain genetik ternak, jenis kelamin, dan umur ternak. Menurut Hidayat et al. (2015) faktor-faktor sebelum pemotongan yang dapat mempengaruhi berat potong antara lain genetik, spesies, bangsa, tipe ternak, jenis kelamin, pakan, bahan adiktif termasuk umur ternak. Faktor-faktor tersebut merupakan faktor-faktor yang berpengaruh terhadap pertumbuhan dan perkembangan sapi potong. Nusi et al. (2011), menyatakan bahwa kenaikan berat potong berhubungann dengan pertumbuhan dan perkembangan dari bagian-bagian tubuh atau karkas.

\section{Berat Karkas}

Berdasarkan data penelitian pada tabel 1 terlihat bahwa nilai rataan berat karkas sapi potong lokal Sulawesi Utara adalah 136,025 kg/ekor dengan kisaran 106 $\mathrm{kg}-171 \mathrm{~kg} / \mathrm{ekor}$. Dari data tersebut dapat dilihat bahwa berat karkas sapi potong lokal Sulawesi Utara di RPH Manado tergolong kecil mengikuti berat potong yang dihasilkan. Hafid et al. (2013), menyatakan bahwa Sapi PO jantan mempunyai rataan berat karkas $203 \mathrm{~kg}$, hasil ini lebih besar dibandingkan dengan hasil penelitian yang didapatkan di RPH Manado yaitu 136,025 kg. Hasil yang sama juga didapatkan dari penelitian Carvalho et al. (2010) yang memperoleh bobot karkas sebesar 195,00 kg. Faktor-faktor tersebut terjadi karena 
Tabel 1. Nilai rataan berat potong, berat karkas dan persentase karkas ternak sapi potong lokal Sulawesi Utara yang dipotong di RPH Manado

\begin{tabular}{cll}
\hline No & \multicolumn{1}{c}{ Variabel } & Nilai Rata - Rata \pm SD \\
\hline 1. & Berat Potong $(\mathrm{kg})$ & $271,475 \pm 34,129$ \\
2. & Berat Karkas $(\mathrm{kg})$ & $136,025 \pm 16,477$ \\
3. & Persentase Karkas $(\%)$ & $50,168 \pm 1,694$ \\
\hline
\end{tabular}

proporsi tulang, otot, dan lemak sebagai komponen utama karkas dipengaruhi oleh berat hidup, dan laju pertumbuhan. Kadar laju pertumbuhan, nutrisi, umur dan berat tubuh adalah faktor-faktor yang mempunyai hubungan erat antara satu dengan yang lain, dan dapat secara individu atau kombinasi mempengaruhi komposisi tubuh atau karkas. Umur seleksi untuk berat potong yang tinggi secara relatif juga mempengaruhi komposisi tubuh dan karkas (Soeparno, 2005). Menurut Wiyatna (2007), berat karkas ternak sapi bervariasi dipengaruhi oleh bobot hidup, bangsa, jenis kelamin, makanan dan kondisi tubuh ternak.

\section{Persentase Karkas}

Berdasarkan data penelitian pada Tabel 1 terlihat bahwa nilai rataan persentase karkas sapi potong lokal Sulawesi Utara yang dipotong di RPH Manado 50,168\% dengan kisaran 47,14 \% $54,46 \%$. Data tersebut lebih besar dibandingkan dengan hasil penelitian yang diperoleh Wiyatna (2007) yaitu 44,00\%. Penelitian ini juga tidak berbeda jauh dengan hasil penelitian Ngadiyono et al. (2008), yaitu berkisar antara 49,64\% $50,69 \%$. Hal yang sama juga diperoleh dari penelitian Carvalho et al. (2010) dengan persentase karkas $49.40 \%$. Dalam penelitian Hafid et al. (2013) memperoleh persentase karkas yang cukup besar yaitu 67,23\%. Persentase karkas dipengaruhi oleh bangsa, umur, jenis kelamin dan sistem pemeliharaan (Phillips, 2001). Faktor-faktor tersebut merupakan faktor-faktor yang berpengaruh terhadap berat karkas sapi potong lokal Sulawesi Utara. Perentase karkas akan meningkat dengan meningkatnya berat potong (Forrest et al. 1975).

\section{KESIMPULAN}

Berdasarkan hasil penelitian disimpukan bahwa ternak sapi potong lokal Sulawesi Utara yang di potong di RPH 
Manado masih tergolong rendah dilihat dari aspek berat potong dan berat karkas.

\section{DAFTAR PUSTAKA}

Carvalho, M. C., Soeparno dan N. Ngadiyono. 2010. Pertumbuhan dan produksi karkas Sapi Peranakan Ongole dan Simmental Peranakan Ongole jantan yang dipelihara secara feedlot. Buletin Peternakan. 34(1) : 38-46.

Firdaus, A., T. Susilawati, M. Nasich dan Kuswati. 2012. Pertambahan bobot badan harian Sapi Brahman Cross pada bobot badan dan Frame Zize yang berbeda. J. Ternak Tropika 13(1): 48-62.

Forrest, J. C., E. D. Aberle, H. B. Hedrick. M. D. Judge and R. A Merkel. 1975. Principles Of Meat Science. W. H. Freeman and Company. San Fransisco.

Hafid, H., Nuraini dan Herman. 2013. Karakteristik karkas dan bagianbagian karkas Sapi Peranakan Ongole jantan dan betina pada peternakan rakyat di Provinsi Sulawesi Tenggara. Prosiding. Seminar Nasional Teknologi Peternakan dan Veteriner.

Hidayat, M. A., Kuswati dan T. Susilawati. 2015. Pengaruh lama istirahat terhadap karakteristik karkas dan kualitas fisik daging Sapi Brahman Cross Steer. Universitas Brawijaya, Malang. Jurnal Ilmu-ilmu Peternakan. 25(2) : 71-79.

Malewa, A. 2009. Penaksiran bobot badan berdasarkan lingkar dada dan panjang badan Domba Donggala. J. Agroland 16 (1): 91-97.

Nusi, M., R. Utomo dan Soeparno. 2011. Pengaruh penggunaan tongkol jagung dalam Complete Feed dan suplementasi Undegrade Protein terhadap pertambahan bobot badan dan kualitas daging pada Sapi Peranakan Ongole. Buletin Peternakan 35(3): 173-181.

Ngadiyono, N., G. Murdjito, A. Agus dan U. Supriyana. 2008. Kinerja produksi Sapi Peranakan Ongole jantan dengan pemberian dua jenis konsentrat yang berbeda. J. Indon. Trop. Anim. Agric. 33(4): 282-289.

Philips, C. J. C. 2001. Principles of Cattle Production. Biddles Ltd, Guildford and King's Lynn. England

Soeparno. 2005. Ilmu dan Teknologi Daging. Cetakan ke-4. Gadjah Mada University. Yogyakarta.

Wiyatna, M. F. 2007. Perbandingan indek sapi-sapi indonesia (sapi bali, madura, po) dengan Sapi Australia Commercial Cross (ACC). Jurnal Ilmu Ternak 1 (7): 22-25

Yosita, M., S. Undang, dan E.Y. Setyowati. 2012. Persentase karkas, tebal lemak punggung dan indeks perdagingan Sapi Bali, Peranakan Ongole dan Aurtralian Commersial Cross. Diakses pada http://jurnal.unpad.ac.id/ejournal/art icle/view/887/993. 23 September 2019. 